Iwona Pirogowicz*, Dominika Ceglecka**, Łukasz Gojny**, Mateusz Patyk ${ }^{* *}$, Magdalena Frej-Mądrzak**, Paweł Popecki ${ }^{* *}$, Grzegorz Gąszczyk ${ }^{* * * *}$, Krystyna Pawlas*

\title{
The analysis of the exhaled nitric oxide in a group of patients with asthma, aged 3-18
}

\section{Analiza poziomu wydzielanego tlenku azotu w grupie pacjentów $z$ astma $w$ wieku od 3 do 18 lat}

\begin{abstract}
* Dr n. med. Iwona Pirogowicz, dr hab. n. med. Krystyna Pawlas, Hygiene Department, Wroclaw Medical University, J. Mikulicza-Radeckiego 7 St. 50-435 Wrocław, Poland, e-mail: iwona.pirogowicz@umed.wroc.pl

** Dominika Ceglecka, Łukasz Gojny, Mateusz Patyk, Paweł Popecki, Student Science Club of Health Promotion and Disease Prevention, Wroclaw Medical University,Wroclaw, J. Mikulicza-Radeckiego 7 St., 50-435
\end{abstract} Wrocław, Poland

\author{
*** Dr n. med. Magdalena Frej-Mądrzak, Department of Basic Sciences, Wro- \\ claw Medical University, Chałubińskiego 4 St., 50-368 Wrocław, Poland \\ **** Dr n. med. Grzegorz Gasszczyk, Pulmonology and Allergy Center, Kar- \\ pacz, Myśliwska 13 St., 58-540 Karpacz, Poland
}

Keywords: respiratory hypersensitivity, airway obstruction, nitrogen monoxide, adolescent

Słowa kluczowe: nadreaktywność dróg oddechowych, obturacja dróg oddechowych, tlenek azotu, młodzież

\section{Abstract}

The aim of this study was to analyse the results of exhaled nitric oxide examination in a group of patients with hyper-responsiveness. The study was performed on a group of 297 children who underwent spirometry, examination of exhaled nitric oxide, skin prick test and stress probe in years 2010-2012 in Pulmonology and Allergy Centre in Karpacz. Mean age of patients was 11.86. Patients were divided into four groups: with diagnosed asthma with bronchial hyper-responsiveness (BHR), with described asthma without BHR and a group with $\mathrm{BHR}$ without diagnosed asthma. The results of the study confirmed the presence of higher amount of exhaled nitric oxide in patients with asthma and bronchial hyper-responsiveness. The elevation of NO concentration correlated with age; there was no significant difference between sexes.

(C) IOŚ-PIB

\section{INTRODUCTION}

Asthma is a chronic illness of the airway tract, which affects all from the small to the big bronchi. It was believed that asthma symptoms were connected with pathological changes in the lobar and segmental bronchi. Recent studies indicate an importance of the changes in the small and smallest bronchioles, as well [van der Wiel \& ten Hacken, 2013]. Main symptoms of an asthma such as spastic cough, dyspnoea and wheezes are an effect of the bronchial hyper-responsiveness (BHR), which can be described as an parallel syndrome [Rasmussen \& Taylor, 2002]. It is important to differentiate these two entities to perform more effective and individualized treatment [Collins \& Parson, 2011].

Widely available diagnostic methods such as the spirometry, the stress test and an allergy testing are not sufficient enough to fulfil the new expectations. New diagnostic and differential tests are looked for. Measurements of the exhaled nitric oxide [FeNO] seem to be encouraging.

\section{Streszczenie}

Celem pracy była analiza wyników badania ilości wydychanego tlenku azotu w grupie pacjentów z nadreaktywnością dróg oddechowych. Przebadano grupę 297 dzieci, u których przeprowadzono badanie spirometryczne jak i badanie ilości wydychanego NO (Nitric Oxide - tlenek azotu), testy skórne oraz próbę wysiłkowa. Badania przeprowadzono w Centrum Pulmonologii i Alergologii w Karpaczu, w latach 2010-2012. Średnia wieku pacjentów wyniosła 11,86. Pacjentów podzielono na 4 grupy: ze zdiagnozowana astma, z nadreaktywnościa oskrzeli, z opisana astma bez nadrekatywności, z nadreaktywnością bez zdiagnozowanej astmy. Wyniki badania potwierdziły większą koncentrację NO u pacjentów ze zdiagnozowana astmą I nadreaktywnościa oskrzeli. Podwyższone stężenie NO korelowało z wiekiem, nie wykazano natomiast znaczącej statystycznie różnicy między płciami.

\section{OBJECTIVE}

The aim of this study was the analysis of the results of exhaled nitric oxide [FeNO] levels in a group of patients with diagnosed asthma or BHR. Furthermore, the possible correlation between once sex, age, diagnosed ailments and the outcome of the FeNO test was assessed.

\section{MATERIALS AND METHODS}

\subsection{Study Subjects}

This study was performed on 297 kids: 144 girls and 153 boys, recruited from the outpatients of Pediatric Pulmonology Department from the "Pulmonology and Allergy Centre" in Karpacz, during years 2010-2012. All patients were inhabitants of the Lower Silesia area. These kids were directed in to diagnose or assess the severity state of asthma. Diagnosis and classification of 
asthma were based on clinical history and currently guidelines. Among all the patients to research group, we chose only these kids, who went through examination of nitric oxide concentration in exhaled air, skin prick test to detect the allergy and confirmation origin of allergic asthma, and performed the stress test.

\subsection{FeNO Measurement}

FeNO measurement was performed with "Medisoft analyser FeNO" before and after stress test. This is a simple and noninvasive diagnostic test, which enables the precise determination of the condition of respiratory tracts. [Taylor \& Palmay, 2010] This survey includes four steps: inspiration, exhaust, continuation of exhaust and results of research. In the first stage of research, patients take a deep breath. The beginning of exhalation takes place after 3 seconds, which is illustrated by appearing on the screen icon and audible signal. After the beep, patient starts to breath lasting about $12 \mathrm{~s}$, during which he should keep the ball placed in the mouthpiece at the level indicated by the bar. The next audible signal announces the end of this study. Test results are shown on the screen immediately after the finish. The measured parameters are: the maximum value of the exhaust of nitric oxide (NO Exhale (ppb)) and averaged over speed of expiratory flow $(\mathrm{VE})(\mathrm{NO} \mathrm{Ex})(\mathrm{ml} / \mathrm{sec})$.

\subsection{Skin Prick Testing}

The methods of skin prick test involve placing a substance, which are allergen in skin punctures. We perform a positive control with a solution of histamine and negative with physiological saline solution. The interpretation of results should be made after the end of $20 \mathrm{~min}$, by measuring the bubble size and infiltration with a ruler. Number of surveyed allergens depends on the suspected aetiology.

\subsection{The stress test}

The study provocation of stress test was performed on a treadmill R5100 with a simultaneous monitoring heart rate by heart rate monitor. The effort was gradually increased during the 6-8 min, until the $80-90 \%$ of maximum heart rate (calculated according to the formula $=220-$ age of patient). Value ventilation should reach $40-60 \%$ of the estimated maximum ventilation, defined as $(F E V 1 \times 35)$. This test is completed when it reaches the target ventilation or cardiac function, where it should be at least $4 \mathrm{~min}$.

\subsection{Statistical Analysis}

The results were compared and analysed with GraphPad Prism 6. The normality of distribution was tested by Shapiro-Wilk test and Kolmogorov-Smirnov test. Next, all parameters with normal distribution were analysed with Student's $t$-test. These non-parametric methods by means of Mann-Whitney test or Wilcoxon test.

\section{RESULTS}

There were 297 children in age 3-18 years old, who had performed stress test and FeNO measurements during 2010-2012. There was $n=279(93.94 \%)$ patients with diagnosed asthma, and $n=213(71.72 \%)$ with bronchial hyperresponsiveness (Table 1.) Among the studied distinguished two another groups: with described asthma without BHR $n=80(26.94 \%)$, and a group with BHR without diagnosed asthma $n=14(4.71 \%)$. There was no significant difference between them $(p>0.05)$ (Fig. 1). The amount of FeNO and VE NO Ex in a group of patients with asthma and BHR was significantly higher than in a group with diagnosed asthma without BHR ( $p=0.0232$; Fig. 2$)$. In this research group, there were 202 children with proved skin prick test allergy, and 95 kids with negative skin test. There was no statistically significant difference in the levels of FeNO and VE NO Ex between that groups.

Further, we have analysed the amount of exhaled NO and FEV1 before and after stress test, as a confounder. There was no significant difference in the level of FeNO. Results of FEV1 were meaningly lower after probe $p<0.0001$ (Table 1).

Pearson's correlation test revealed a significant correlation between age and amount of exhaled nitric oxide either before or after the stress test (Table 2). There were no dependencies between once sex and FeNO results.

\section{DISCUSSION}

Asthma and bronchial hyperresponsiveness (BHR) are chronic diseases affecting respiratory system, and significantly may impact ones quality of life. According to Global Initiative for Asthma (GINA) guidelines, the aim of the treatment is to control the disease and improve once health-related quality of life (HR-QoL) [Scichilone \& Braido, 2013]. To improve the HR-QoL medics have to meet the criteria:

Table 1. Characteristics of patients with diagnosed asthma and or bronchial hyperresponsiveness [BHR]. FEV1 - forced expiratory volume in $1 \mathrm{~s}, \mathrm{FeNO}$ - fractional nitric oxide concentration in exhaled breath, VE NO Ex - averaged over speed of expiratory flow

\begin{tabular}{|l|c|c|c|c|}
\hline \multicolumn{1}{|c|}{ Characteristic } & Total & Male (n=153) & Female (n= 144) & $P$-value \\
\hline Age (years) & 11.85 & 11.84 & 11.85 & $<0.0001$ \\
\hline Asthma, $\mathrm{n}(\%)$ & $279(93.94)$ & $143(48.15)$ & $136(45.79)$ & $<0.0001$ \\
\hline BHR, $\mathrm{n}(\%)$ & $213(71.72)$ & $108(36.36)$ & $105(35.35)$ & $<0.0001$ \\
\hline Asthma without BHR, $\mathrm{n}(\%)$ & $80(26.94)$ & $41(13.80)$ & $39(13.13)$ & 0.1884 \\
\hline Isolated BHR, $\mathrm{n}(\%)$ & $14(4.71)$ & $6(2.02)$ & $8(2.69)$ & $<0.0001$ \\
\hline FEV1 before stress test, mean (SD) & $2.715(1.008)$ & $2.658(1.01)$ & $2.775(1.02)$ & $<0.0001$ \\
\hline FEV1 after stress test, mean (SD) & $2.573(1.006$ & $2.542(1.02)$ & $2.607(0.99)$ & $<0.0001$ \\
\hline FeNO before stress test, mean (SD) & $57.13(50.68)$ & $56.84(52.38)$ & $57.44(48.99)$ & $<0.0001$ \\
\hline FeNO after stress test, mean (SD) & $57.32(48.83)$ & $56.99(51.47)$ & $57.68(46.03)$ & $<0.0001$ \\
\hline VE NO Ex [ml/sec], before stress test, mean (SD) & $48.04(10.78)$ & $48.48(11.23)$ & $47.57(10.30)$ & $<0.0001$ \\
\hline VE NO Ex [ml/sec], after stress test, mean (SD) & $48.63(9.74)$ & $48.68(9.63)$ & $48.57(9.88)$ & $<$ \\
\hline
\end{tabular}




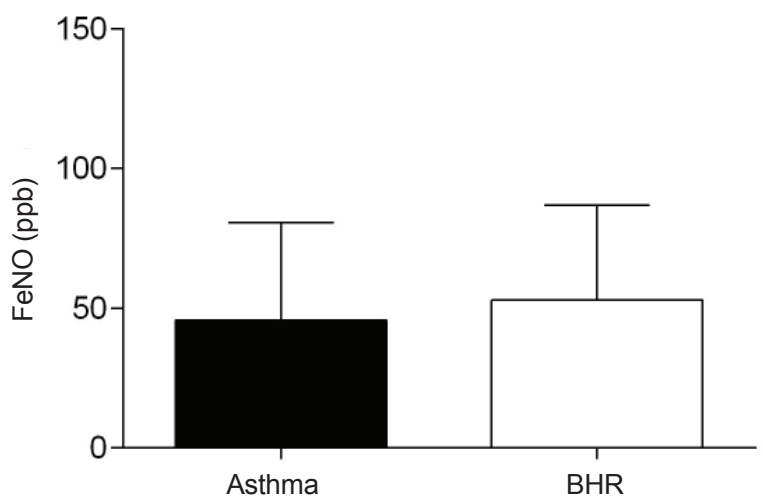

Fig. 1. Difference of amount of exhaled nitric oxide (FeNO) between a group of patients with isolated bronchial hyperresponsiveness (BHR) and a group of patients with asthma

- Eliminate occasional flare-ups.

- Reduce medicament doses to effective minimum.

- Eliminate side effects.

To achieve these goals, the therapeutic process should be personalized as much as possible [Haverkamp Dempsey, 2007]. To reach that point asthma should be different from isolated BHR. In most of the previous study, BHR was described as a cardinal feature of asthma. In fact, BHR may be another pathologic process, which requires another way of treatment [Colins \& Parsons, 2011]. In the current research group, there were only $n=80(26.94 \%)$ with asthma without $B H R$ and $n=14$ (4.71\%) with diagnosed $B H R$ without asthma. We expect that the real number of patients with isolated BHR is higher. Because of the retrospective character of this study, we could not check in detail the diagnostic process. To accurately differentiate these diseases, new methods are necessary.

Nitric oxide measurements seem to be promising. NO is recognized as a multifunctional molecule in human and animal organisms. This highly reactive compound plays a role inter alia in: neurotransmission, vasodilatation, bronchodilatation, and inflammation process [Nathan \& Xie, 1994]. In pathophysiology of asthma, the last two functions are most important. The exact role is not clear. On the one hand, it may act as a proinflammatory mediator predisposing to the development of bronchial hyperresponsiveness (BHR). On the other, NO is a weak smooth muscle relaxant. In the early 1990s, NO measurements were introduced for the first time [Gustafsson \& Leone, 1991]. About 20 years after introduction, FeNO measurements are still an experimental diagnostic test. Mostly FeNO results are used as an additional,

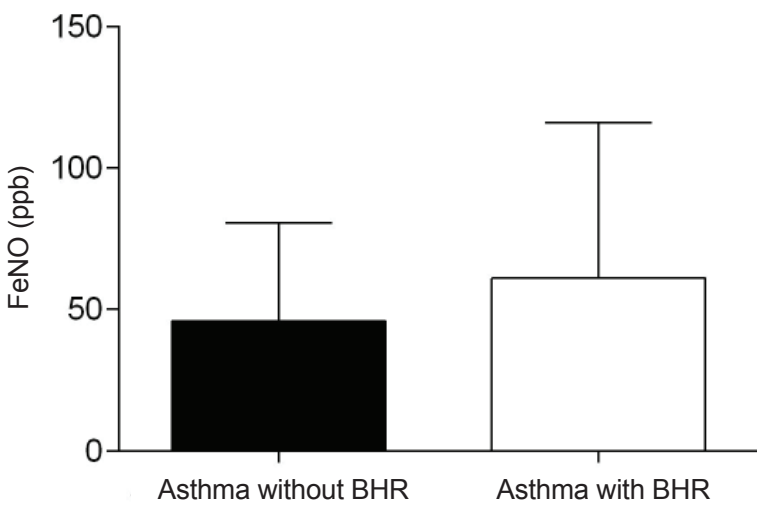

Fig. 2. Difference of amount of exhaled nitric oxide (FeNO) between a group of patients with isolated asthma and a group of patients with co-existing asthma and bronchial hyperresponsiveness (BHR)

less valuable markers. American Thoracic Society suggests that FeNO assessment may be used inter alia to:

- Diagnose eosinophilic airway inflammation (strong recommendation, moderate quality of evidence).

- Support the diagnosis of asthma in situations in which objective evidence is needed (weak recommendation, moderate quality of evidence).

- Monitor airway inflammation in patients with asthma (strong recommendation, low quality of evidence).

- Determine the likelihood of steroid responsiveness in individuals with chronic respiratory symptoms possibly due to airway inflammation (strong recommendation, low quality of evidence).

Still is underlined that in spite of advance technology and standardization before FeNO will be useful as a clinical tool, more work is still needed [Jongste \& Carraro, 2011; Moon \& Choi 2013]. In our study, the amount of FeNO and VE NO Ex in a group of patients with asthma and $\mathrm{BHR}$ was significantly higher than in a group with diagnosed asthma without BHR $p=0.0232$ (Fig. 2).

There are more and more metaanalysis concerning the usefulness of exhaled NO analysis. Jartti and Wendelin-Saarenhovi (2012) questioned the helpfulness of this tool. In their opinion, there are too many factors affecting FeNO values. They find a correlation between once height, age, sex, cooperation, nasal inflammation, food, smoking or environmental exposures, to levels of exhaled NO. Our results do not confirm the relationship between once sex, but there is a strong correlation between patients age. In our opinion, nasal inflammation or coexisting infections may be a strong factor affecting the FeNO result. We did not

Table 2. Results of the Pearson's correlation test between age and stress test's parameters

\begin{tabular}{|c|c|c|c|c|}
\hline & Age vs. distance & Age vs. HR & $\begin{array}{l}\text { Age vs. FeNO } \\
\text { before stress test }\end{array}$ & $\begin{array}{l}\text { Age vs. FeNO } \\
\text { after stress test }\end{array}$ \\
\hline$R$ & 0.2837 & 0.03499 & 0.1715 & 0.2067 \\
\hline$R^{2}$ & 0.0805 & 0.001225 & 0.02941 & 0.04272 \\
\hline$P$-value & $<0.0001$ & 0.5535 & 0.003 & 0.0003 \\
\hline Significant (alpha $=0.05$ ) & Yes & No & Yes & Yes \\
\hline
\end{tabular}


analyse this part because of the lack in medical documentation. We suspect that FeNO measurements may be helpful in diagnosis of diseases, which imitate asthma like Gastro Esophageal Reflux Disease [Pirogowicz \& Patyk, 2013].

A step forward was made by Montuschi et al. [2013], who designed the "Electronic Nose" to analyse the exhaled air. With the gas chromatography and mass spectrometry, they found several volatile organic compounds (VOCs). This method was useful especially in combination with FeNO measurements to discriminate asthmatics and healthy people. This tool may be helpful in future to diagnose another lung disorders like COPD, cancer [Montuschi \& Santonico, et. al, 2013].

\section{REFERENCES}

COLLINS R.A., PARSONS F., DEVERELL, M., HOLLAMS E.M., HOLT P.G., SLY, P.D. 2011. Risk factors for bronchial hyperresponsiveness in teenagers differ with sex and atopic status. Journal of allergy and clinical immunology 128,2: 301-307.

DE JONGSTE J.C., CARRARO S., HOP W.C., \& BARALDI E. 2009. Daily telemonitoring of exhaled nitric oxide and symptoms in the treatment of childhood asthma. American Journal of Respiratory and Critical Care Medicine 179,2: 93-97.

DWEIK R.A., BOGGS P.B., ERZURUM S.C., IRVIN C.G., LEIGH M.W., LUNDBERG J.O., OLIN A.C., PLUMMER A.L., TAYLOR D.R. 2011. An official ATS clinical practice guideline: Interpretation of Exhaled Nitric Oxide Levels (FENO) for Clinical Applications. American Journal of Respiratory and Critical Care Medicine 184,5: 602-615.

GUSTAFSSON L.E., LEONE A.M., PERSSON M.G., WIKLUND N.P., MONCADA S. 1991. Endogenous nitric oxide is present in the exhaled air of rabbits, guinea pigs and humans. Biochemical and Biophysical Research Communications 181,2: 852-857.

HAYERKAMP H.C., DEMPSEY J.A., PEGELOW D.F., MILLER J.D., ROMER L.M., SANTANA M. \& ELDRIDGE M.W. 2007. Treatment of airway inflammation improves exercise pulmonary gas exchange and performance in asthmatic subjects Journal of allergy and clinical immunology 120: 39-47.

http://www.ginasthma.org/ accessed on 10 October 2013. Global strategy for asthma management and prevention. Vancouver (WA): Global Initiative for Asthma (GINA). 2012. GINA REPORT.

JARTTI T., WENDELIN-SAARENHOVI M., HEINONEN I., HARTIALA J., VANTO T. 2012. Childhood asthma management guided by repeated FeNO measurements: a meta-analysis. Paediatric Respiratory Reviews 13,3: 178-183.

MONTUSCHI P., SANTONICO M., MONDINO, Ch., PENNAZZA G., MANTINI G., MARTINELLI, E., CAPUANO R., CIABATTONI G., PAOLESSE R., DI NATALE C., BARNES P.J., FCCP

\section{CONCLUSION}

Nitric oxide measurements may be helpful in assessment of asthma control. The results of the study confirmed the presence of the higher amount of exhaled nitric oxide in patients with bronchial hyperresponsiveness than in patients with diagnosed asthma. There was significant correlation between age and FeNO results (in Pearson's correlation test $r=0.2067$, and $p<0.001$ ). The FeNO measurement may be used as a complementary method in asthma diagnosis. There was no statistically significant difference between groups of girls and boys. Present methods require standardization.

\& D'AMICO A. 2010. Diagnostic performance of an electronic nose, Fractional Exhaled Nitric Oxide, and Lung Function Testing in Asthma. CHEST 137, 4: 790-796.

MOON H.G., CHOI Y.R., SHIM Y-S., CHOI K-I., LEE J-H., KIM J-S., YOON S-J., PARK H-H., KANG C-Y., JANG H.W. (2013). Extremely sensitive and selective NO probe based on villi-like WO3 nanostructures for application to exhaled breath analyzers. ACP Publication 5,21: 10591-10596.

NATHAN C., XIE Q-W. 1994. Nitric oxide synthases: roles, tolls, and controls. Cell 78,6: 915-918.

PIROGOWICZ I., PATYK M., POPECKI P., RUDNICKI J., GOJNY L., POKORSKI M. 2013. Lung function in patients with gastro-esophagea reflux disease and respiratory symptoms. Neurobiology of Respiration, Advances in Experimental Medicine and Biology 788: 161-166.

RASMUSSEN F., TAYLOR D.R., FLANNERY E.M., COWAN J.O., GREENE J.M., HERBISON G.P., Sears M.R. 2002. Outcome adulthood of asymptomatic airway hyperresponsiveness in childhood: A longitudinal population study. Pediatric Pulmonology 34,3: 164-171.

SCICHILONE N., BRAIDO F., TAORMINA S., POZZECCO E., PATERNO A., BAIARDINI I., CASOLARO V., CANONICA G.W., BELLIA V. 2013. Is health-related quality of life associated with upper and lower airway inflammation in asthmatics? Hindawi Publishing Corporation, BioMed Research International, Article ID539290, pages 7.

TAYLOR D.R., PALMAY R., COWAN J.O., HERBISON G.P. 2011. Long term performance characteristics of an electrochemical nitric oxide analyser. Respiratory Medicine 105,2: 211-217.

VAN DER WIEL E., TEN HACKEN N.H.T., POSTMAN D.S., VAN DEN BERGE M. 2013. Small-airways dysfunction associates with respiratory symptoms and clinical features of asthma: a systematic review. Journal of allergy and clinical immunology 131,3: 646-657. 